\title{
KEPEMIMPINAN KEPALA SEKOLAH \\ BERBASIS KECERDASAN EMOSIONAL DI SMAN 1 SOPPENG RIAJA KABUPATEN BARRU PROPINSI SULAWESI SELATAN
}

\section{SARIFUDDIN}

\author{
(Universitas Muslim Indonesia (UMI) Sulawesi Selatan) \\ Email: sarif.28@yahoo.co.id
}

\begin{abstract}
This study is aimed at investigating; (1) What is the purpose of principal leadership emotional intelligence based at SMA 1 Soppeng Riaja, Barru Regency? (2) How does the effort of the application of principal leadership emotional intelligence based conducted by the principal of State School of Senior High School 1 Soppeng Riaja Barru? To answer these problems researcher used qualitative approach. The methods of data collection are: (a) observation, (b) interview, and (c) documentation. While the methods of data analysis used analytical descriptive and reported with thick description. The results of the data analysis illustrated that; (1) The purposes of principal leadership emotional intelligence based at SMAN 1 Soppeng Riaja, Barru are: to improve the content standard and school competence, to improve standards of learning process, to improve the standard of learning process, to improve the standard of facilities and infrastructure, to improve school management standards, to improve financial standards, to improve the standard of educational assessment, and to improve the school readiness and external support. (2) The implementation of leadership through four aspects of emotional intelligence. The first, the current situation is the control emotion that caused by the events of life, work pressure, and the pressure of personal problems in doing tasks and responsibilities. The second, understanding of emotional intelligence is understanding the feelings of self and others in controlling the expression of emotions and get benefit of the potential of emotions as a source of energy and resources. The third, the ability of emotional intelligence is self-actualizing potential that include intentionality, creativity, toughness, and interpersonal relationship to motivate and mobilize their staff to work together to participate in the success of school organizational goals. The fourth, values and beliefs of emotional intelligence is prioritization of affection, angle of view, intuition, personal power and integrity in carrying out the policies and in collaboration with his staff.
\end{abstract}

\section{Abstrak}

Penelitian ini bertujuan untuk menyelidiki; (1) Apa tujuan kepemimpinan kepala sekolah berbasis kecerdasan emosional di SMA Negeri 1 Soppeng Riaja, kabupaten Barru? (2) Bagaimana upaya penerapan kepemimpinan kepala sekolah berbasis kecerdasan emosional 
yang dilakukan oleh kepala SMA Negeri 1 Soppeng Riaja, Kabupaten Barru? Untuk menjawab permasalahan tersebut peneliti menggunakan pendekatan kualitatif. Metode pengumpulan data yang dipakai ialah: (a) observasi, (b) interview, dan (c) dokumentasi. Sedangkan metode analisis datanya menggunakan metode descriptif analitis dan dilaporkan dengan deskripsi mendalam (thick description). Hasil analisis data menggambarkan bahwa; (1) Tujuan kepemimpinan kepala sekolah berbasis kecerdasan emosional di SMA Negeri 1 Soppeng Riaja, Kabupaten Barru, antara lain: Untuk memperbaiki standar isi dan kompetensi sekolah, memperbaiki standar proses pembelajaran, memperbaiki standar pendidik dan tenaga kependidikan, memperbaiki standar sarana dan prasarana, memperbaiki standar pengelolaan sekolah, memperbaiki standar pembiayaan, memperbaiki standar penilaian pendidikan, dan memperbaiki kesiapan sekolah dan dukungan eksternal. (2) Upaya penerapan kepemimpinannya melalui empat aspek kecerdasan emosional. Pertama, Situasi saat ini yaitu pengendalian emosi yang ditimbulkan oleh peristiwa hidup, tekanan pekerjaan, dan tekanan masalah pribadi dalam mengerjakan tugas dan tanggungjawabnya. Kedua, Pemahaman kecerdasan emosional yaitu pemahaman perasaan diri dan orang lain dalam mengendalikan ekspresi emosi serta memanfaatkan potensi emosi sebagai sumber energi dan sumber informasi. Ketiga, Kemampuan kecerdasan emosional yaitu pengaktualisasian potensi diri yang meliputi intensionalitas, kreativitas, ketangguhan, dan hubungan antar pribadi dalam memotivasi dan menggerakkan stafnya agar bekerjasama berpartisipasi dalam meraih keberhasilan menuju kesempurnaan tujuan organisasi sekolah. Kempat, Nilai-nilai dan keyakinan kecerdasan emosional yaitu pengedepanan kasih sayang, sudut pandang, intuisi, daya pribadi dan integritas dalam melaksanakan kebijakan-kebijakan dan dalam bekerjasama dengan stafnya.

Kata Kunci: Kepemimpinan, Kepala Sekolah, Kecerdasan Emosional

\section{Pendahuluan}

Kepemimpinan dan manajemen pendidikan sangatlah penting karena pertumbuhan sistem pendidikan tanpa memfungsikan pengelolaan atau manajemen pendidikan tidak mungkin dapat membina pertumbuhan sekolah. Prosedur pengelolaan harus diterapkan secara sistematis. Dinamika sistem pendidikan nasional adalah organisasi yang dapat menampung berbagai kemungkinan kegiatan manajemen sesuai dengan pertumbuhan dan perkembangan dinamika masyarakat.

Pengelolaan sekolah secara luas, meliputi bidang kesiswaan, bangunan atau gedung, personil, keuangan, peralatan, proses belajar-mengajar, dan hubungan sekolah dengan masyarakat. Selain itu, pengelolaan juga meliputi masalah 
kepemimpinan, komunikasi serta hubungan internal dan eksternal. Mulyasa ${ }^{1}$ mengemukakan bahwa hubungan yang harmonis antara sekolah dan pihak lain akan membentuk: (1) saling pengertian, antara sekolah, masyarakat, orang tua dan lembaga-lembaga lain, (2) saling membantu antara sekolah dan masyarakat karena mengetahui manfaat arti dan pentingnya peranan masing-masing, (3) kerjasama yang erat antara sekolah dengan berbagai pihak yang ada di masyarakat dan mereka merasa ikut bertanggungjawab atas suksesnya pendidikan sekolah.

Kepala sekolah sebagai pengelola pendidikan harus mampu memberikan makna yang tepat serta mampu menetapkan berbagai kebijakan sekolah untuk dapat membuat sekolah berkualitas. Pengelola atau menajer sekolah harus mempunyai strategi manajemen. Wahab mengemukakan, hal terpenting dari pembaharuan dalam pengelolaan pendidikan adalah lahirnya ide-ide baru dari pengelolanya yang dapat mendorong peningkatan dan pengembangan sumber daya manusia yang ada dalam lembaga kependidikan. Ide-ide baru tersebut akan menjadi kekuatan sosial untuk pembaharuan, termasuk pembaharuan pengeloaan pendidikan pada umumnya dan sekolah pada khususnya ${ }^{2}$.

Ide-ide baru/kritis tersebut, tidak muncul dari kecerdasan intelektual saja, tetapi juga dari kecerdasan lain, diantaranya kecerdasan emosional sebagaimana Cooper dan Sawaf mengemukakan "this feeling can grow expansively into enthusiasm, a sense of flow, and even passion for your work"3. Melalui kesadaran yang intensif orang akan menjadi kreatif sebagaimana dikemukakan May yang dikutip Perkins "...creatif is the encounter of the intensively conscious human being with his world"4.

Kepala sekolah selaku manajer pendidikan dalam menerapkan kecerdasan emosional kepemimpinannya sangat dipengaruhi oleh berbagai faktor, diantaranya: faktor guru, staf, siswa, orang tua siswa, dana, sarana serta suasana dan faktor lingkungan dimana sekolah itu berada. Oleh karena itu, kepala sekolah harus memiliki kecerdasan emosional yang memadai.

Wahjosumidjo mengemukakan ada delapan fungsi kepala sekolah selaku manajer, yaitu: (1) kepala sekolah bekerja dengan dan melalui orang lain, (2) kepala sekolah bertanggung jawab dan mempertanggung jawabkan, (3) dengan waktu dan sumber daya yang terbatas, seorang kepala sekolah harus mampu menghadapi berbagai persoalan, (4) kepala sekolah harus berfikir secara analitik dan konsepsional, (5) kepala sekolah sebagai juru penengah, (6) kepala sekolah sebagai politisi, (7) kepala sekolah adalah seorang diplomat, dan (8) kepala

\footnotetext{
${ }^{1}$ E Mulyasa, Menjadi Kepala Sekolah Profesional, (Bandung: Remaja Rosdakarya), 2007, 187.

2 Abdul Azis Wahab, "Mencari Arah Baru dalam Mengelola Sekolah," Majalah Mimbar Pendidikan, IKIP (Bandung), 1996, 32.

3 Robert Cooper and Ayman Sawaf, Executive EQ, Emotional Intelligency in Business, (London: Orion Business Book, 1997), 40.

${ }^{4}$ David Perkins, The Mind's Best Work: a New Psychology of Creatif Thinking, (Cambridge: Harvard University Press, 1983), 58.
} 
sekolah berfungsi sebagai pengambil keputusan yang sulit ${ }^{5}$.

Tugas dan fungsi kepala sekolah tersebut sangat memerlukan kecerdasan emosional tinggi. Kecerdasan emosional atau yang dikenal dengan Emotional Quotient (EQ) yang dipopulerkan oleh Goleman, merupakan kemampuan: (a) mengenali emosi, (b) mengelola emosi, (c) kemampuan memotivasi diri, (d) kemampuan mengenali emosi orang lain dan (e) kemampuan membina hubungan dengan orang lain 6 .

Menurut Agustian kecerdasan emosi adalah: kemampuan merasakan, memahami secara efektif menerapkan daya dan kepekaan emosi sebagai sumber energi, informasi, koneksi dan pengaruh manusia ${ }^{7}$. Emosi adalah bahan bakar yang tidak tergantikan bagi otak agar mampu melakukan penalaran yang tinggi. Emosi menyulut kreatifitas, kolaborasi, inisiatif, dan trasformasi; sedangkan penalaran logis berfungsi untuk mengantisipasi dorongan-dorongan yang keliru, untuk kemudian menyelaraskan dengan proses kehidupan dengan sentuhan manusiawi ${ }^{8}$. Disamping itu, emosi pun ternyata salah satu kekuatan penggerak: "Bukti-bukti menunjukkan bahwa nilai-nilai dan watak dasar seseorang dalam hidup ini tidak berakar pada IQ tetapi pada kemampuan emosional"9.

Dari pemikiran di atas dapat disimpulkan bahwa kecerdasan emosional merupakan salah satu faktor penentu keberhasilan pendidikan, karena dengan kecerdasan emosional tersebut orang akan mampu mengendalikan diri, memelihara dan memacu motivasi untuk terus berupaya dan tidak mudah putus asa dalam meraih keberhasilan belajarnya.

Berdasarkan latar belakang masalah tersebut di atas, penulis tertarik melakukan kajian terhadap penerapan kecerdasan emosional dalam kepemimpinan kepala sekolah yang dilakukan di SMA Negeri 1 Soppeng Riaja, dengan rumusan masalah sebagai berikut: (1) Apa tujuan kepemimpinan kepala sekolah berbasis kecerdasan emosional di SMA Negeri 1 Soppeng Riaja, kabupaten Barru? dan (2) Bagaimana upaya penerapan kepemimpinan kepala sekolah berbasis kecerdasan emosional yang dilakukan oleh kepala SMA Negeri 1 Soppeng Riaja, Kabupaten Barru?

\section{Metode Penelitian}

\section{Jenis Penelitian}

Berdasarkan analisis dan taraf pembahasan, penelitian ini berjenis kualitatif yang bertujuan untuk memahami (understanding) dunia makna yang

\footnotetext{
${ }^{5}$ Wahjosumidjo, Kepemimpinan Kepala Sekolah, (Jakarta: PT Raja Grafindo Persada, 2007), 97.

${ }^{6}$ Danah Zohar dan Ian Marshal, SQ Kecerdasan Spritual, (Bandung: Mizan, 2007), 3.

${ }^{7}$ Ary Ginanjar Agustian, Rahasia Sukses Membangun Kecerdasan Emosi dan Spiritual, ESQ, (Jakarta: Arga, 2005a), 280.

${ }^{8}$ Ary Ginanjar Agustian, Rahasia Sukses Membangun Kecerdasan Emosi dan Spiritual, ESQ, (Jakarta: Arga, 2005a), 280.

9 Ary Ginanjar Agustian, Rahasia Sukses Membangun Kecerdasan Emosi dan Spiritual, ESQ, (Jakarta: Arga, 2005a), 280.
} 
disimpulkan dalam perilaku masyarakat (guru) menurut perspektif masyarakat (lingkungan sekolah) itu sendiri ${ }^{10}$, karena bersifat understanding, maka pelaporannya bersifat diskriptif dan naratif ${ }^{11}$.

\section{Fokus dan Ruang Lingkup Penelitian}

Fokus penelitian ini pada penerapan kecerdasan emosional dalam kepemimpinan kepala sekolah yang dilakukan di SMA Negeri 1 Soppeng Riaja.

Adapun ruang lingkup yang akan diamati adalah tujuan dan penerapan kecerdasan emosional kepala sekolah yang dilakukan di SMA Negeri 1 Soppeng Riaja.

\section{Sumber Data}

Sumber data utama (Primer), yaitu sumber data yang memberikan data langsung kepada pengumpul data ${ }^{12}$. Mengingat instrumen pengumpulan data utama dalam penelitian ini adalah observasi, maka sumber data utama dalam penelitian ini yaitu kepala sekolah guru/staf dan siswa. Selain dari sumber data tersebut peneliti juga mengambil dari pengamatan selama penelitian berlangsung.

Sumber data pelengkap (Sekunder), yaitu sumber data yang tidak langsung memberikan data kepada pengumpul data ${ }^{13}$. Sumber data pendukung dalam penelitian ini ialah dokumen-dokumen, seperti profil sekolah, program pembiasaan akhlak siswa, bentuk-bentuk pembiasaan, hasil evalusi peningkatan akhlak siswa, dan data-data yang memberikan informasi tentang problem yang terjadi saat pelaksanaan program pembiasaan akhlak siswa berikut solusinya.

\section{Metode Pengumpulan Data}

Instrumen pengumpulan data yang dipakai pada penelitian ini, antara lain:

\section{a. Observasi}

Observasi penulis gunakan sebagai instrumen untuk memperoleh data utama (primer). Observasi yang penulis lakukan yaitu observasi partisipatif secara terbuka. Penulis dalam hal ini berperan sebagai pengamat dan sekaligus menjadi anggota resmi dari kelompok yang diamati dan diketahui oleh subjek penelitian. Melalui observasi partisipatif ini data yang diperoleh lebih lengkap dan bisa sampai mengetahui pada tingkat makna dari setiap perilaku yang tampak.

Observasi dilakukan untuk mengamati proses kepemimpinan pendidikan berbasis kecerdasan emosional kepala sekolah sehingga

10 Basrowi dan Sukidin, Metode Penelitian Kualitatif Perspektif Mikro, (Surabaya: Insan Cendikia, 2002), 2.

${ }^{11}$ Imam Suparyogo dan Tobroni, Metodologi Penelitian Sosial Agama, (Bandung: Remaja Rosdakarya, 2001), 8.

${ }^{12}$ Sugiyono, Memahami Penelitian Kuantitatif: Dilengkapi dengan Contoh Proposal dan Laporan Penelitian, (Bandung: Alfabeta, 2005), 62.

${ }^{13}$ Sugiyono, Memahami Penelitian Kuantitatif: Dilengkapi dengan Contoh Proposal dan Laporan Penelitian, (Bandung: Alfabeta, 2005), 62. 
sekolah tersebut berhasil.

b. Interview

Pola interview yang digunakan ialah wawancara bebas terpimpin, yakni sebelumnya telah dibuat draf atau panduan interview yang berfungsi sebagai pengarah agar interview tetap efektif dan efisien. Selain itu agar penulis mempunyai arsip dokumen dari data yang diperoleh dari responden. Sasaran interview dalam penelitian ini adalah kepala sekolah dan guru dilingkungan sekolah tersebut.

\section{c. Dokumentasi}

Dokumentasi menurut penulis adalah instrumen pendukung utama yang sangat valid, karena dokumentasi dapat dijadikan bukti akurat. Dokumentasi dalam penelitian ini digunakan untuk memperoleh data pendukung (sekunder) tentang identitas sekolah, identitas guru dan lainlain yang berhubungan dengan kecerdasan emosional dalam kepemimpinan pendidikan.

\section{Metode Analisis Data}

Jenis penelitian ini adalah penelitian kualitatif. Karena jenis penelitian kualitatif, menurut Miles dan Huberman (1984), analisis datanya menggunakan analisis data kualitatif, yaitu melakukan analisis secara interaktif dan berlangsung secara terus menerus sampai tuntas hingga datanya sudah mencapai taraf "redundanct" atau "jenuh"14. Aktivitas analisis data tersebut, meliputi data reduction, data display, dan data conclusion drawing/verifikation ${ }^{15}$.

\section{Hasil Pembahasan}

1. Tujuan Kepemimpinan Kepala Sekolah Berbasis Kecerdasan Emosional di SMA Negeri 1 Soppeng Riaja, Kabupaten Barru

\section{a. Memperbaiki Standar Isi dan Kompetensi Sekolah}

Kebijakan tersebut diantaranya berupa perbaikan standar isi dan kompetensi sekolah, meliputi:

1) Perbaikan dokumen KTSP dan Pengesahan oleh Dinas Pendidikan Propinsi Sulawesi Selatan.

Dokumen KTSP SMA Negeri 1 Soppeng Riaja secara umum sebelumnya telah tersedia, akan tetapi dokumen tersebut memiliki beberapa kekurangan antara lain: (1) Silabus dan RPP yang dimiliki belum lengkap untuk seluruh standar kompetensi dan kompetensi dasar pada setiap mata pelajaran, (2) karena adanya ketidaklengkapan tersebut dokumen KTSP belum disahkan oleh Dinas Pendidikan Propinsi Sulawesi Selatan.

${ }^{14}$ (Nasution, 1991: 217)

15 Harun Rasyid, Metode Penelitian Kualitatif Bidang Ilmu Sosial dan Agama, (Pontianak: STAIN Pontianak, 2000), 123; Suparyogo dan Tobroni, Metode Penelitian Kuantitatif Kualitatif dan RED, (Bandung: Alfabeta, 2001), 193; dan Sugiyono, Metode Penelitian Kuantitatif Kualitatif dan RED, (Bandung: Alfabeta, 2007), 246. 
Bentuk kongkrit tindakan kepala sekolah dalam perbaikan ini ialah melakukan pelengkapan secara bersama-sama di sekolah pada hari yang telah ditentukan, kemudian meminta pengesahan langsung secara intensif pada Dinas Pendidikan Propinsi Sulawesi Selatan.

2) Prosedur Penyusunan Dokumen

Penyusunan dokumen kepala sekolah sebagai pimpinan pembentuk tim penyusun yang dipimpin langsung dengan langkah konkrit menyusun program kerja, jadwal kerja tim, serta memberdayakan guru untuk melakukan analisis Permen No. 22 tahun 2005 tentang Standar Isi, dan Permen No. 23 tahun 2005 tentang SKL, serta analisis SWOT (Strengths [kekuatan] Weakness [kelemahan] Opportunity [peluang], Threat [ancaman] sekolah.

3) Struktur dan Muatan KTSP

Perbaikan yang dilakukan untuk struktur dan muatan KTSP berupa pembenahan program muatan lokal dan program pengembangan pembenahan diri. Termasuk penertiban pembelajaran sistem SKS, penetapan ketuntasan minimal untuk semua mata pelajaran minimal $75 \%$ dari standar ketuntasan ideal, penetapan kriteria kenaikan kelas minimal 75\% dari standar ketuntasan minimal pada setiap mata pelajaran, penetapan dan penggunaan strategi pendidikan kecakapan hidup yang terintegrasi pada setiap mata pelajaran, serta menerapkan strategi berbasis keunggulan lokal dan global.

\section{b. Memperbaiki Standar Proses Pembelajaran}

Melalui kepemimpinan berbasis kecerdasan emosional yang diterapkannya, kepala SMAN 1 Soppeng Riaja, Drs. Muhammad Akil, M.Pd., melakukan beberapa pemenuhan standar proses pembelajaran pada beberapa aspek yang belum memenuhi standar, antara lain:

1) Perangkat Pembelajaran

Perangkat pembelajaran di SMA Negeri 1 Soppeng Riaja masih belum lengkap, sementara perangkat yang berbasis TI (tekhnologi informasi) disamping terbatas pengetahuan oprasional guru tentangnya masih terbatas sehingga perlu pelatihan.

Kepala sekolah telah mengupayakan workshop baik yang dilaksanakan di sekolah sendiri ataupun bergabung dengan sekolah atau instansi lain yang menyelenggarakannya, hal ini dilakukan untuk meningkatkan kemampuan dewan guru dan tenaga administrasi dalam mengoperasikan perangkat berbasis komputer baik dalam pelaksanaan pembelajaran maupun administrasi sekolah.

2) Pelaksanaan Proses Pembelajaran

Pada pelaksanaan proses pembelajaran ada beberapa aspek yang perlu dilakukan pemahaman dan perubahan mengajar dari paradigma lama (guru aktif) dengan paradigma baru (siswa aktif, guru mediator), selain itu dengan komitmen SKM (sekolah katagori mandiri) dan sekolah rintisan SSN (sekolah standar nasional) yang menerapkan 
pengelolaan pembelajaran dengan sistem pindah ruang kelas (moving class) yang membutuhkan kelas mata pelajaran.

Perbaikan yang dilakukan oleh kepala sekolah yaitu bekerjasama dengan guru menyiapkan jadwal konsultasi mata pelajaran, melakukan remedial sepanjang semester, serta membentuk dan menetapkan penasehat akademik yang dapat mendeteksi potensi siswa.

\section{c. Memperbaiki Standar Pendidik dan Tenaga Kependidikan}

Kepemimpinan kepala sekolah berbasis kecerdasan emosional yang diterapkan oleh kepala SMA Negeri 1 Soppeng Riaja bertujuan untuk memenuhi standar pendidikan dan tenaga kependidikan pada beberapa indikator. Pemenuhan ini dilakukan dengan cara memperbaiki aspek peningkatan kemampuan guru dalam pengembangan bahan ajar dan aspek pemenuhan tanaga kependidikan. Salah satu bentuk peningkatan kemampuan guru melalui diikutkan program beasiswa S2 dan workshop sertifikasi. Selain itu pemenuhan tenaga edukatif, perpustakaan dan laboran melalui pengangkatan tenaga honorer.

\section{d. Memperbaiki Standar Sarana dan Prasarana}

Berdasarkan hasil verifikasi dan kondisi SMA Negeri 1 Soppeng Riaja diketahui ada beberapa sarana dan prasarana yang perlu dilengkapi atau dilakukan perbaikan, diantaranya ruang kelas, ruang perpustakaan, laboratorium biologi, laboratorium fisika, laboratorium kimia, laboratorium komputer, ruang kepala sekolah, ruang guru, ruang TU (tata usaha), ruang BK (bimbingan dan konseling), ruang UKS dan ruang OSIS.

Perpustakaan dilakukan pelengkapan buku referensi dan sistem sirkulasi komputerisasi, sedangkan untuk laboratorium fokus pada pelengkapan alat peraga dan bahan-bahan praktek. Adapun pemenuhan ruang kepala sekolah, guru dan BK dibuatkan ruang baru, sedangkan untuk ruang guru dan BK yang lama dijadikan ruang OSIS dan UKS.

\section{e. Memperbaiki Standar Pengelolaan Sekolah}

Berdasarkan indikator sekolah kategori mandiri ada beberapa aspek standar pengelolaan sekolah di SMA Negeri 1 Soppeng Riaja yang perlu diperbaiki.

1) Pedoman Pengelolaan Sekolah

Pada pedoman pengelolaan sekolah indekator yang menjadi sasaran perbaikan kepala sekolah yaitu: (1) menyempurnakan dokumen standar KTSP (kurikulum tingkat satuan pendidikan), (2) melengkapi buku pedoman mata pelajaran yang sesuai dengan potensi dan minat siswa, (3) melengkapi panduan penilaian melalui menjajaki potensi peserta didik dengan cara menyempurnakan format penilaian hasil belajar untuk ranah kognitif, afektif, psikomotorik.

2) Pelaksanaan Kegiatan Sekolah

Pada pelaksanaan kegiatan sekolah yang dilakukan kepala sekolah adalah melengkapi penunjang kompetensi siswa melalui kerjasama dengan instansi atau lembaga pendidikan lain pada aspek 
kecakapan hidup, muatan lokal, pendidikan berbasis keunggulan lokal dan global bahkan internasional, serta mewujudkan uji kompetensi bersama.

3) Kesiswaan

Pada aspek kesiswaan, selain mengadakan kegiatan reuni rutin kepala sekolah membuat wadah komunikasi berbasis internet (facebook and blog) antara guru, siswa dan alumni. Hal ini dimaksudkan agar siswa dan alumni ikut berpartisipasi menyumbangkan pikirannya memajukan dan mengawasi perkembangan prestasi sekolah.

4) Evaluasi

Untuk memenuhin standar pengelolaan pendidikan pada aspek evaluasi ada beberapa indikator yang dibenahi oleh kepala sekolah, yaitu melakukan evaluasi diri terhadap kinerja sekolah, melakukan evaluasi pengembangan KTSP, melakukan evaluasi pendayagunaan pendidikan dan tenaga kependidikan, dan memperbaiki status akreditasi kemudian mempertahankannya.

5) Sistem Informasi Manajemen

Diantara ciri sekolah yang baik adalah sekolah yang memiliki sistem informasi manajemen yang efektif, efisien dan mudah diakses. Oleh karena itu kepala sekolah bersama wakil kepala sekolah urusan humas menggalakkan sistem informasi manajemen melalui pembuatan website untuk memberikan informasi tentang sekolah, begitu juga menampung tanggapan masyarakat tentang pengelolaan sekolah.

\section{f. Memperbaiki Standar Pembiayaan}

Biaya pada suatu pelaksanaan merupakan suatu yang vital, termasuk pada penyelenggaraan pendidikan. Selama ini pendidikan gratis sudah menjadi animo masyarakat sehingga motivasi masyarakat untuk sekolah cukup besar, namun disisi lain memiliki dampak negatif bagi pihak sekolah selaku penyelenggara pendidikan. Pembiayaan yang dibutuhkan sekolah jauh lebih besar dari subsidi yang diberikan pemerintah, sehingga pihak sekolah harus mampu survive. Untuk hal ini kepala sekolah bersama komite sekolah melakukan beberapa kebijakan yang berkenaan dengan dana.

\section{g. Memperbaiki Standar Penilaian Pendidikan}

Perbaikan standar penilaian pendidikan yang dilakukan kepala sekolah SMA Negeri 1 Soppeng Riaja Drs. Muhammad Akil, M.Pd sejak penerapan kepemimpinan berbasis kecerdasan emosional mencakup tiga aspek, (1) perangkat penilaian, yaitu melengkapi format penilaian dengan kolom yang lebih jelas dan obyektif, rencana terjadwal, bahanbahan pembuatan soal ulangan/remedial/semester yang lengkap, disertai kisi-kisi. (2) pelaksanaan penilaian, melakukan penilaian madiri maupun kerjasama dengan lembaga lain dalam melakukan penilaian pencapaian kompetensi siswa. (3) hasil penilaian, memperbaiki rerata nilai UN (ujian nasional) dimana nilai rata-rata UN tiga tahun terakhir hanya 7,00. Langkah perbaikan melalui mengintensifkan kelas 
tambahan, pembahasan soal UN tahan-tahun sebelumnya, try out hingga dua kali. Selain itu upaya spritual juga dilakukan melalui doa bersama dan muhasabah.

\section{h. Memperbaiki Kesiapan Sekolah dan Dukungan Eksternal}

Untuk mensukseskan program SKM (sekolah katagori mandiri) di SMA Negeri 1 Soppeng Riaja, Drs. Muhammad Akil, M.Pd menyatukan tekat menyiapkan sekolah dan dukungan pihak eksternal sekolah dengan tindakan-tindakan kongkrit, diantaranya: (1) mensosialisasikan program SKM (sekolah katagori mandiri) dengan sistem beban SKS pada stakeholder sekolah. Sosialisasi ini melibatkan (bekerjasama) perguruan tinggi terdekat yaitu STAIS DDI Mangkoso, karena sistem beban SKS memiliki kesamaan baik dalam persiapan pembelajaran, pelaksanaan proses pembelajaran, maupun pelaksanaan evaluasinya. (2) untuk mendukung pelaksanaan program SKM (sekolah katagori mandiri) dengan sistem beban SKS dipersiapkan tenaga administrasi (TU) dan perangkat pendukung komputerisasi.

\section{Penerapan Kepemimpinan Kepala Sekolah Berbasis Kecerdasan Emosional}

\section{a. Situasi Saat Ini}

1) Peristiwa Hidup

Berbagai aspek yang dialami kepala SMA Negeri 1 Soppeng Riaja dalam peristiwa hidup yang dihadapinya, salah satunya mengendalikan emosi dengan baik sehingga tidak mempengaruhi perasaannya saat menghadapi pekerjaan dalam mengelola sekolah. Kepala sekolah dengan pengendalian emosinya dapat menghindarkan tekanan-tekanan perasaan. Disadari atau tidak hal tersebut akan mengaktifkan kecerdasan emosianal kepala sekolah dalam menghadapi pekerjaan sehingga dapat melaksanakan dan menjalankan tugas dengan baik.

Penerapan kecerdasan emosional yang dilakukan kepala SMA Negeri 1 Soppeng Riaja disadari manfaatnya dan ditingkatkan menuju taraf yang lebih baik untuk dapat memanfaatkan potensi diri dengan optimal. Hal tersebut dilakukan untuk menunjang keberhasilan hidup yang lebih memuaskan dan membantu keberhasilan orang lain atau orang-orang yang dipimpinnya serta keberhasilan sekolah dalam mencapai tujuan.

Kepala SMA Negeri 1 Soppeng Riaja mampu mengendalikan emosi dengan lebih baik guna terbebas dari tekanan-tekanan peristiwa hidup, karena kepala SMA Negeri 1 Soppeng Riaja menyadari bahwa kecerdasan emosional yang terkendali dapat memberikan makna yang mendalam dalam kepemimpinan pendidikan dan pengelolaan sekolah.

2) Tekanan Pekerjaan 
Kepala SMA Negeri 1 Soppeng Riaja dalam menjalankan tugas dan tanggung jawab tidak terpengaruh oleh tekanan pekerjaan. Dari data dan wawancara dengan stafnya mengenai taraf kecerdasan emosional kepala sekolah dalam aspek tekanan pekerjaan menunjukkan berada pada taraf yang baik.

Pada taraf kecerdasan emosional tersebut, kepala SMA Negeri 1 Soppeng Riaja dapat mengerjakan seluruh tugas dan tanggung jawabnya dengan baik. Akan tetapi hanya tertumpu pada pekerjaan formal yang diperintahkan oleh atasannya, dalam hal ini kepala Dinas Pendidikan Kabupaten Barru. Pekerjaan lain yang menjadi wewenangnya dalam mengelola sekolah belum disadari sebagai tugas prioritas, tapi sebagai tugas penunjang.

Kepala SMA Negeri 1 Soppeng Riaja terbebas dari tekanan pekerjaan formal. Pekerjaan lain yang berupa kebijakan dari dirinya dijadikan prioritas kedua. Hal tersebut terkadang menjadikan dirinya tidak menyadari kemandiriannya sebagai kepala sekolah yang mandiri dan membuat kecerdasannya dengan kebijakan tidak berinisitaif untuk memunculkan ide-ide baru dalam mengelola sekolah. Jika dibiarkan pengelolaan sekolah hanya dilakukan secara intelektual hal tersebut akan menumpulkan kecerdasan emosional dan daya refleks yang dimilikinya.

3) Tekanan Masalah Pribadi

Penerapan kecerdasan emosional yang berkenaan dengan aspek tekanan masalah pribadi yang dilakukan oleh kepala SMA Negeri 1 Soppeng Riaja berada dalam taraf yang baik. Perasaan kepala sekolah tidak dipengaruhi oleh masalah-masalah pribadi dalam mengelola sekolah. Kesadaran kepala sekolah dalam mengendalikan emosi pada aspek masalah pribadi dapat ditingkatkan guna menunjang pengelolaan sekolah agar dapat lebih berhasil.

Peningkatan penerapan kecerdasan emosional dalam aspek masalah pribadi adalah salah satu cara yang dilakukan kepala sekolah untuk memulihkan kemampuan berpikir. Kalau tekanan masalah pribadi dibiarkan mempengaruhi emosi secara batin dan fisik, maka akan berdampak buruk terhadap kehidupan, kesehatan, dan cara penyelesaian pekerjaan. Adanya usaha pemeliharaan kestabilan emosi dalam masalh pribadi, berarti memotivasi diri untuk berusaha menggapai kehidupan yang lebih baik dengan menyentuh bagianbagian dari otak yang masih pasif menjadi aktif dan memungkinkan untuk terus meningkatkan intelegensi sepanjang hayat.

\section{b. Pemahaman Kecerdasan Emosional}

1) Kesadaran Emosi Diri

Kesadarn diri berkaitan dengan emosi. Kepala SMA Negeri 1 Soppeng Riaja dalam kecerdasan emosional yang menyangkut masalah kepekaan terhadapat prasaan diri sendiri dan orang lain 
berada pada taraf yang baik. Kepala SMA Negeri 1 Soppeng Riaja juga telah memperlakukan perasaan orang lain dengan baik.

Suatu kepemimpinan harus dimulai dari mengenali diri sindiri dengan mendalam, kemudian mengenali diri orang lain yang akan dipimpinnya. Walaupun cara kepala SMA Negeri 1 Soppeng Riaja sudah mengendalikan diri dan menerapknan emosi dengan baik sehingga dapat menjadikannya suatu kekuatan dalam menyelesaikan berbagai pekerjaan dengan berhasil, tetapi perlu juga ditingkatkan, karena perubahan kesadaran diri dan keasadaran orang lain selalu berubah mengikuti aneka ragam sensasi dan motivasi yang terjadi pada dirinya. Maka kontinyuitas berlatih yang efektif sangatlah dibutuhkan.

2) Ekspresi Emosi

Kecerdasan emosional kepala SMA Negeri 1 Soppeng Riaja dalam berekspresi dan mengelola sekolah berada pada taraf yang baik. Akan tetapi usaha untuk meningkatkannya menuju menuju taraf yang lebih baik tidak akan menjadi sia-sia dalam kehidupan yang mengharapkan berhasilan yang lebih baik. Dengan demikian usaha mengendalikan emosi untuk berekspresi akan tampil lebih meyakinkan bagi diri sendiri dan orang lain yang akan menciptakan kepercayaan diri yang tinggi.

Emosi ada pada setiap orang, tapi tidak semua orang mampu mengenali dan memanfaatkan potensi emosi yang dimiliki sebagai kekuatan dahsyat mencapai keberhasilan kepemimpinan. Emosi adalah sumber energi dan sumber informasi yang bersifat batiniyah. Kemampuan membedakan perasaan yang ada pada diri dan kemampuan menerima informasi dari perasaan orang lain merupakan persyaratan dasar bagi setiap orang yang ingin menjadi pemimpin.

3) Kesadaran Emosi terhadap Orang Lain

Taraf kecerdasan emosional kepala SMA Negeri 1 Soppeng Riaja dalam aspek kesadaran emosi terhadap orang lain sangan baik. Memahami perasaan dan masalah orang lain, berfikir dari sudut pandang mereka, serta menghargai perbedaan pendapat orang lain tentang berbagai hal adalah suatu tindakan yang dapat menenangkan diri sendiri dan orang lain yang akan melahirkan kecerdasan lain, kenyamanan dan kehidupan secara sehat, serta dapat bekerja dengan luwes dan menyenangkan.

Oleh karena itu, kepala SMA Negeri 1 Soppeng Riaja selalu melatih kesadaran emosi terhadap orang lain dengan meningkatkan kemampuan yang maksimum untuk dijadikan modal dalam kepemimpinan pengelolaan sekolah. Perlakuan terhadap perasaan yang baik akan memberikan motivasi yang tinggi terhadap orang yang dipimpinnya, dan bantuan serta kesetiaan akan datang dari orang yang dipimpinnya dalam mencapai keberhasilan tujuan sekolah.

\section{c. Kemampuan Kecerdasan Emosional}


1) Intensionalitas

Kecerdasan emosional kepala SMA Negeri 1 Soppeng Riaja pada dimensi kemampuan kecerdasan emosional dalam aspek intensinalitas berada pada taraf yang masih kurang baik. Hal ini menunjukkan, perhatian kepada sekolah belum menyentuh pada apa yang harus dilakukan sesuai dengan perannya untuk dapat berhasil dalam mengelola sekolah. Kecerdasan emosional dalam kepemimpinan merupakan suatu kesatuan dari berbagai aspek perasaan. Dengan dimikan, aspek-aspek yang telah berada pada taraf baik tidak akan menjadikan aspek lain menjadi baik.

Untuk mengantisipasi kondisi tersebut, kepala SMA Negeri 1 Soppeng Riaja melakukan introspeksi pada penghambat kinerjanya dalam pengelolaan sekolah.

2) Kreativitas

Kreativitas yang merupakan salah satu aspek kecerdasan emosional yang diterapkan oleh kepala SMA Negeri 1 Soppeng Riaja berada pada taraf yang sangat baik. Taraf ini menunjukkan bahwa bobot kreativitas kepala sekolah dalam mengelola sekolah sangat memadai untuk dapat membuat sekolah maju dan berkembang dengan baik.

Kreativitas kepala sekolah dalam membawa sekolah menuju sekolah yang berkatagori mandiri sangat dirasakan oleh para stafnya. Hal ini terlihat dari beberapa perubahan dibeberapa sektor menjadi lebih baik. Menurut koordinator wakil kepala sekolah pengendalian emosi kepala sekolah dapat mengubah emosi diri kepala sekolah menjadi sumber energi dan semangat sehingga kebijakankebijakannya intuitif dan kreatif.

3) Ketangguhan

Kecerdasan emosional dalam aspek ketangguhan pada diri kepala SMA Negeri 1 Soppeng Riaja berada pada taraf yang baik. Artinya kepala sekolah dalam melaksanakan pekerjaan dan tanggung jawabnya telah dapat menyelesaikan dengan ketangguhan.

Sikap dan ketangguhan kepala sekolah telah diisi dengan bobot ketangguhan seperti mempunyai tekad yang original dalam mengelola sekolah, melakukan perubahan untuk menciptakan kondisi dan hasil sekolah yang lebih baik, membuka diri untuk berbagai masalah yang berkenaan dengan kemajuan sekolah, dan tidak pernah takut gagal dalam melakukan sesuatu yang dipikir baik untuk dikerjakan. Gairah kerja terus dipelihara untuk selalu mendapatkan sesuatu yang lebih menguntungkan.

4) Hubungan Antar pribadi

Hubungan antar pribadi kepala SMA Negeri 1 Soppeng Riaja menunjukkan terdapat pada taraf yang baik. Kondisi tersebut memberikan peluang kepada kepala sekolah agar dapat memberikan dorongan terhadap orang lain untuk berprestasi. Sebagai seorang 
pemimpin, kepala sekolah sangat membutuhkan orang-orang yang memahami pekerjaan dan kinerjanya. Melalui hubungan antar pribadi yang baik kepala sekolah dapat menggerakkan personilnya dengan baik pula. Hal ini tentunya harus didukung oleh kemauan untuk memotivasi stafnya agar bergerak ke arah tujuan yang lebih kreatif.

Hubungan antar pribadi mencerminkan jaringan organisasi untuk mempartisipasikan orang-orang dalam kegiatan organisasi, menetapkan kapasitas orang-orang untuk berpartisipasi, dan menciptakan saling ketergantungan. Apabila hubungan ini selalu dipupuk dengan baik dengan nilai-nilai yang mengarah pada kualitas, inovatif dalam menggerakkan roda rutinitas, maka kerjasama lebih terjalin dan kemudahan dalam meraih keberhasilan segera diraih munuju kesempurnaan tujuan organisasi sekolah.

5) Ketidakpuasan Konstruktif

Dewasa ini para pemimpin masa depan sering menuju pada arah yang berlawanan dalam memajukan organisasinya. Pemimpin saat ini menunjukkan sikap hormat, percaya, terbuka, bersifat ingin tahu, empati, serta mau terus belajar dalam menghadapi penolakan dan kritikan-kritikan. Pemimpin saat ini menyambut ketidakpuasan konstruktif sebagai suatu rangsangan untuk mendapatkan kualitas dan inovasi. Oleh karena itu kepala SMA Negeri 1 Soppeng Riaja sebagai pemimpin yang memiliki kecerdasan emosional tinggi mencari berbagai cara untuk mengesahkan konflik sebagai bagian yang sehat dan alami dalam budaya organisasi.

Taraf ketidakpuasan konstruktif di SMA Negeri 1 Soppeng Riaja berada pada taraf yang cukup. Untuk menghadapi kritik dan konflik kepala SMA Negeri 1 Soppeng Riaja selalu melakukan penyelesaian yang mendamaikan konflik dan kritik tersebut dengan argumentatif demi kebersamaan sehingga gejolak yang muncul terjadi dapat diselesaikan dengan baik dan solutif.

\section{d. Nilai-Nilai dan Keyakinan Kecerdasan Emosional}

1) Kasih Sayang

Taraf penerapan kecerdasan emosional pada aspek kasih sayang yang dilakukan oleh kepala SMA Negeri 1 Soppeng Riaja berada pada taraf baik. Kasih sayang yang diperlihatkan kepala sekolah dapat diterima oleh pihak lain di sekolah, tetapi kasih sayang tersebut belum digunakan sebagai alat untuk mengarahkan orang-orang menuju keberhasilan.

Salah satu bentuk kasih sayang kepala sekolah memberikan maaf kepada stafnya yang melakukan pelanggaran kedisiplinan dalam taraf kewajaran. Memaafkan adalah suatu yang diperbuat untuk membebaskan sebagian perasaan tertekan oleh penyesalan, kemarahan, bahkan kebencian. Memaafkan adalah melepaskan energi yang terperangkap sehingga dimanfaatkan untuk keperluan lain. Apabila rasa kasih sayang tersebut diungkapkan dalam bentuk 
perbuatan, seseorang dapat keluar dari statusnya sebagai korban dan melepaskan diri dari perasaan takut, kecewa, keinginan menyalahkan orang lain, cemburu, iri hati atau dengki. Luka-luka yang ditimbulkan dari emosi lama dapat dihapus dan diperbaiki, namun luka-luka tersebut dapat dijadikan bibit untuk transendensi dan transformasi.

Menerapkan kasih sayang yang benar dalam kehidupan merupakan implikasi dari kecerdasan emosional yang akan menjadikan seseorang memiliki rasa syukur. Pemimpin yang mempunyai repotasi istimewa selalu memimpin dengan sikap dan ungkapan syukur. Hal ini penting untuk memperbaiki kehidupan organisasi. Perhatian yang diungkapkan dengan kasih sayang, akan menghasilkan balasan kebaikan yang berlipat ganda.

2) Sudut Pandang

Sudut pandang yang merupakan salah satu aspek dalam kecerdasan emosional yang diterapkan kepala SMA Negeri 1 Soppeng Riaja berada pada taraf baik. Kondisi ini dapat menguntungkan, baik untuk kehidupan pribadi maupun organisasi. Sudut pandang akan memberikan warna terhadap laju kehidupan organisasi. Sudut pandang juga memberikan corak yang dinamis dari seorang pemimpin pada sisi positif dari segala aspek.

3) Intuisi

Intuisi yang dilakukan kepala SMA Negeri 1 Soppeng Riaja berada pada taraf kurang baik. Intuisi yang ditunjukkan kepala sekolah hanya mengedepankan kuantitas, tidak mengedepankan kualitas yaitu suara hati yang lebih jelas dan lebih dapat dipercaya. Intuisi yang diberikan kepala sekolah kurang transparan sehingga stafnya sulit mengaplikasikannya.

Pengakuan kepala sekolah sendiri memang kurang memperhatikan potensi kecerdasan emosional aspek intuisi ini, karena selama ini baginya intuisi hanya dapat dilakukan oleh pemimpin yang memiliki indra keenam saja. Kepala sekolah berusaha untuk menggali lebih dalam lagi pemahaman tentang intuisi sebagai bagian dari kecerdasan emosionalnya.

4) Radius Kepercayaan

Kepercayaan adalah tempat mulai menghargai kemungkinankemungkinan kreatif pada keragaman dan konflik manusia secara utuh. Makin panjang radius kepercayaan, makin besar peluang untuk berhasil ditengah kesibukan dan ketergesaan penyelesaian pekerjaan. Radius kepercayaan diantaranya berkenaan dengan prilaku seseorang dalam memanfaatkan kepercayaan dalam bekerja dengan keyakinannya, keteguhan, rasa hormat, rasa adil, dan jujur.

Taraf kecerdasan emosional yang optimal akan lebih memberikan peluang yang optimal pula dalam kepemimpinan dan secara kreatif akan menggali apa yang diinginkannya. Taraf 
tersebut adalah taraf ideal dalam mencapai radius kepercayaan dalam organisasi bagi pemimpin.

Berdasarkan hasil penelitian radius kepercayaan kepala SMA Negeri 1 Soppeng Riaja berada dalam taraf baik. Keadaan tersebut menunjukkan bahwa dalam menerapkan radius kepercayaan, kepala sekolah berusaha menerapkan kecerdasan emosionalnya dengan baik pula. Pengelolaan untuk lebih meningkatkan radius kepercayaan ke taraf yang lebih baik harus lebih ditingkatkan.

5) Daya Pribadi

Daya pribadi kepala SMA Negeri 1 Soppeng Riaja berada pada taraf yang baik. Kondisi tersebut menunjukkan bahwa daya pribadi kepala sekolah sebagai pemimpin dalam mengelola sekolah berada pada taraf yang baik. Daya pribadi kepala sekolah ini perlu dipertahankan, bahkan ditingkatkan karena jika daya pribadi rentan tidak akan menghasilkan keberhasilan yang memuaskan.

Daya pribadi menunjukkan kekuatan untuk dapat melaksanakan berbagai aktivitas kehidupan yang tetap bertahan baik dalam kondisi sulit maupun dalam kondisi lancar dan tetap menuju kepada keberhasilan yang diharapkan, bukan hanya untuk keberhasilan diri sendiri tetapi juga untuk keberhasilan orang lain.

Autentisitas atau keaslian menjadi suatu yang dipuji dan dicari di kalangan pemimpin karena merupakan pengembangan alami dari ciri kemampuan diri atau daya pribadi yang dipandang sebagai mendan daya. Pada dasarnya medan daya adalah energi yang tidak hanya terpancar dari pikiran dan tubuh, tetapi juga dari hati yang setiap saat mengirimkan kebenaran emosional secara mendalam untuk dipegang teguh dan diyakini.

6) Integritas

Integritas kepala SMA Negeri 1 Soppeng Riaja berada dalam taraf kurang baik. Setiap staf mungkin dapat berkata bahwa kepala sekolah bekerja dilandasi dengan integritas yang tinggi tetapi kebenaran dari apa yang dilakukan belum dapat dibuktikan. Hal ini menunjukkan taraf yang masih rendah dalam menerapkan kecerdasan emosional aspek integritas. Terdapat bukti yang menunjukkan bahwa hanya dari kedalaman integritas manusia dapat meraih sesuatu dengan menggunakan daya kreatifnya dengan baik.

Seseorang tidak akan memiliki integritas dengan baik tanpa memiliki sikap jujur, akan tetapi orang bisa bersikap jujur walaupun tingkat integritasnya rendah. Hal ini berarti seseorang dapat bersikap jujur tanpa pernah melibatkan diri dalam kerja keras, menghayati sesuat yang benar ataupun yang salah dalam setiap situasi atau dalam memperhitungkan masalah konteks, perasaan, dan waktu tanpa pernah berpikir bahwa sesungguhnya keyakinan tersebut harus diungkapkan diwujudkan saat itu juga. Dengan demikian integritas kepala sekolah yang terdapat pada taraf rentan perlu ditekankan 
kembali agar dapat meningkat menuju taraf yang lebih baik dan dapat memperbaiki peringkat kepemimpinannya menuju tingkat yang lebih baik dan benar.

\section{Kesimpulan}

Berdasarkan hasil analisis data observasi yang diperkuat dengan data hasil interview dan dokumentasi, serta dilakukan pembahasan, maka dapat ditarik beberapa kesimpulan sebagai berikut:

1. Tujuan kepemimpinan kepala sekolah berbasis kecerdasan emosional di SMA Negeri 1 Soppeng Riaja, Kabupaten Barru, antara lain: (1) Untuk memperbaiki standar isi dan kompetensi sekolah, (2) Untuk memperbaiki standar proses pembelajaran, (3) Untuk memperbaiki standar pendidik dan tenaga kependidikan, (4) Untuk memperbaiki standar sarana dan prasarana, (5) Untuk memperbaiki standar pengelolaan sekolah, (6) Untuk memperbaiki standar pembiayaan, (7) Untuk memperbaiki standar penilaian pendidikan, dan (8) Untuk memperbaiki kesiapan sekolah dan dukungan eksternal.

2. Upaya penerapan kepemimpinan kepala sekolah berbasis kecerdasan emosional di SMA Negeri 1 Soppeng Riaja, Kabupaten Barru, melalui empat aspek kecerdasan emosional. Pertama, Situasi saat ini. Pada aspek ini kepala SMA Negeri 1 Soppeng Riaja dalam mengerjakan tugas dan kebijakannya mengendalikan emosi yang ditimbulkan oleh peristiwa hidup, tekanan pekerjaan, dan tekanan masalah pribadi agar tidak dapat mengganggu perasaannya, sehingga dapat mengerjakan tugas dan tanggungjawabnya dengan baik dan efektif. Kedua, Pemahaman kecerdasan emosional. Pada aspek ini kepala sekolah memahami perasaan dirinya dan orang lain, mengendalikan ekspresi emosi serta memanfaatkan potensi emosi sebagai sumber energi dan sumber informasi dalam melaksanakan tugas, tanggungjawab dan kebijakan-kebijakan.

Ketiga, Kemampuan kecerdasan emosional. Pada aspek ini kepala SMA Negeri 1 Soppeng Riaja mengaktualisasikan potensi diri yang meliputi intensionalitas, kreativitas, ketangguhan, dan hubungan antar pribadi dalam memotivasi dan menggerakkan stafnya agar bekerjasama berpartisipasi dalam meraih keberhasilan menuju kesempurnaan tujuan organisasi sekolah. Sedangkan ketidakpuasan konstruktif disikapi sebagai suatu rangsangan untuk mendapatkan kualitas dan inovasi. Kempat, Nilai-nilai dan keyakinan kecerdasan emosional. Pada aspek ini kepala sekolah mengedepankan kasih sayang, sudut pandang, ituisi, daya pribadi dan integritas dalam melaksanakan kebijakan-kebijakan dan dalam kerjasamanya dengan stafnya. 


\section{DAFTAR PUSTAKA}

Agustian, Ary Ginanjar, 2005a, Rahasia Sukses Membangun Kecerdasan Emosi dan Spiritual, ESQ, Jakarta: Arga.

Basrowi dan Sukidin, 2002, Metode Penelitian Kualitatif Perspektif Mikro, Surabaya: Insan Cendikia.

Cooper, Robert and Ayman Sawaf, 1997, Executive EQ, Emotional Intelligency in Business, London: Orion Business Book.

Mulyasa, E, 2007, Menjadi Kepala Sekolah Profesional, Bandung: Remaja Rosdakarya.

Perkins, David, 1983, The Mind's Best Work: a New Psychology of Creatif Thinking, Cambridge: Harvard University Press.

Rasyid, Harun, 2000, Metode Penelitian Kualitatif Bidang Ilmu Sosial dan Agama, Pontianak: STAIN Pontianak.

Sugiyono, 2005, Memahami Penelitian Kuantitatif: Dilengkapi dengan Contoh Proposal dan Laporan Penelitian, Bandung: Alfabeta.

Sugiyono, 2007, Metode Penelitian Kuantitatif Kualitatif dan RED, Bandung: Alfabeta.

Suparyogo dan Tobroni, 2001, Metode Penelitian Kuantitatif Kualitatif dan RED, Bandung: Alfabeta.

Suparyogo, Imam dan Tobroni, 2001, Metodologi Penelitian Sosial Agama, Bandung: Remaja Rosdakarya.

Wahab, Abdul Azis, "Mencari Arah Baru dalam Mengelola Sekolah," Majalah Mimbar Pendidikan, IKIP Bandung, 1996.

Wahjosumidjo, 2007, Kepemimpinan Kepala Sekolah, Jakarta: PT Raja Grafindo Persada.

Zohar, Danah dan Ian Marshal, 2007, SQ Kecerdasan Spritual, Bandung: Mizan. 